\title{
TRUST BUT VERIFY: DOMESTIC POLITICS AND INTERNATIONAL COORDINATION IN U.S. POST-CRISIS FINANCIAL REGULATORY POLICY
}

\author{
NiCHOLAS KEAN TABOR*
}

\begin{abstract}
After the 2008 financial crisis, reforms to financial regulation in the United States developed with an apparent contradiction at their core: While those reforms embraced cooperative international measures, they simultaneously imposed more stringent safeguards on foreign banks opening on American soil. In short, they both ceded and guarded domestic control over U.S. financial regulatory policy.

This Comment examines that contradiction from 2008 to 2010, including through Basel III negotiations and the Dodd-Frank Wall Street Reform and Consumer Protection Act, and attempts to explain the contradiction using an extended rational institutionalist account of international policy development. The domestic actors responsible for U.S. foreign financial policy held distinct preferences for financial reform; when one actor exerted greater control over an institutional locus of the reform process, that actor's preferences
\end{abstract}

* JD/MBA, 2018, The Wharton School/University of Pennsylvania Law School. Former Senior Policy Advisor, National Economic Council, The White House (President Barack Obama). Former Chief of Staff, Promontory Financial Group. The Author wishes to thank Professors William Burke-White and Beth Simmons for their thoughtful guidance in developing this Comment; Eugene Ludwig, for his instruction, his mentorship, and his tireless lifelong work to improve the global financial system; and Sophia Yan, for her insightful comments. 
dominated. The resulting legislation provides a clear demonstration of the explanatory power of domestic politics for international legal and policy outcomes - even in the absence of public attention. 


\section{TABLE OF CONTENTS}

1. Introduction: Domestic Financial Regulation Beyond the

Water's Edge

2. Background: U.S. Domestic Regulation of Foreign

Banking Organizations ..................................................... 898

3. The 2008 Financial Crisis: Transaction Costs and

Costly Transactions 902

4. United States Participation in International Post-Crisis

Financial Regulatory Measures ....

5. Cooperation Meets Defection: The Drafting of

Dodd-Frank. 910

6. Bureaucratic Politics and Low-Public-Saliency Reform ..... 915 


\section{INTRODUCTION: DOMESTIC FINANCIAL REGULATION BEYOND THE WATER'S EDGE}

Midway through the 2008 U.S. Presidential campaign, America's financial house caught fire. Responding to shoddy underwriting practices and a wave of mortgage defaults, U.S. home prices fell by almost ten percent, 1 and mortgage delinquency rates doubled in less than a year. ${ }^{2}$ Collateral calls led to the near-collapse of Bear Stearns, one of the country's oldest investment banks, which JPMorgan Chase purchased in a government-assisted fire-sale. ${ }^{3}$ After seventythree consecutive months of economic growth, the United States was in recession. 4

Just nine days after Bear Stearns announced it was closing its doors, Senator and Presidential candidate Barack Obama gave a speech in New York City outlining six principles for repairing the American financial system. Before an audience of the most senior executives in the U.S. banking industry, he dedicated a large portion of his speech to international-not domestic - financial regulation. "As we reform our regulatory system at home," he said:

we should work with international arrangements, like the Basel Committee on Banking Supervision, the International Accounting Standards Board, and the Financial Stability Forum, to address the same problems abroad. The goal should be to ensure that financial institutions around the world are subject to similar rules of the road, both to make the system more stable and to keep our financial institutions

${ }^{1}$ Fed. Reserve Econ. Database [FRED], SEP/Case-Shiller U.S. National Home Price Index, FED. RESERVE BANK OF ST. LOUIS (Dec. 26, 2017), https://fred.stlouisfed.org/series/CSUSHPINSA [https://perma.cc/8NN3-65HD].

2 FRED, Delinquency Rate on Single-Family Residential Mortgages, Booked in Domestic Offices, All Commercial Banks, FED. RESERVE BANK OF ST. LOUIS (Nov. 27, 2017), https://fred.stlouisfed.org/series/DRSFRMACBS [https://perma.cc/R87UPCME].

3 Associated Press, JPMorgan to Buy Bear Stearns for \$2 a Share, NBCNEws (Mar. 17, 2008), http://www.nbcnews.com/id/23662433/ns/business-us_business/t/jpmorgan-buy-bear-stearns-share [https://perma.cc/WG6Y-EK8T].

4 Bus. Cycle Dating Comm., Nat'1 Bureau of Econ. Research, Determination of the December 2007 Peak in Economic Activity, (Dec. 11, 2008), http://www.nber.org/cycles/dec2008.html [https://perma.cc/8WN2-VUKX]. 
competitive. ${ }^{5}$

Even in an election year, Obama's support for these international arrangements - where regulators in different countries agreed to embrace common standards - was not a strictly partisan issue. As Obama spoke, President George W. Bush coordinated a wide array of market support programs across the G20 countries.6 "I'm a market-oriented guy," he would later comment, "but not when I'm faced with the prospect of a global meltdown."7 Bush appointees followed similar maxims. Just two years earlier, Federal Reserve Chairman Ben Bernanke (whom Bush appointed) had negotiated and advocated strongly for domestic implementation of the Basel II capital accords, saying that "international cooperation and consistency" on large-bank regulation "remains very much in the interest of the United States." 8

Skeptics of international financial regulation also resided on both sides of the aisle. Earlier in March 2008, Treasury Secretary Hank Paulson released a "Blueprint for a Modernized Financial Regulatory Structure," which mentioned the Basel Committee only as an example of "jurisdictional disputes" that "hinde[r] the introduction of new products" and "slo[w] innovation."9 Even Daniel

\footnotetext{
5 Barack Obama, Presidential Candidate, Speech at Cooper Union: Renewing the American Economy (Mar. 27, 2008), http://www.nytimes.com/2008/03/27/us/politics/27text-obama.html

[https://perma.cc/HTD7-GTQ8], in Obama on "Reviving the Economy", N.Y. TIMES.

6 Jeremy Pelofsky, Bush Says Financial Crisis Needs Coordinated Response, REUTERS (Oct. 11, 2008), https://www.reuters.com/article/uk-financial-g7-bushidUKTRE49A1W020081011 [https:// perma.cc/8WN2-VUKX].

7 President George W. Bush, President Bush Discusses Financial Markets and World Economy (Nov. 13, 2008), https://georgewbush-whitehouse.archives.gov/news/releases/2008/11/20081113-4.html [https://perma.cc/5W8YEFL9].

8 Ben S. Bernanke, Chairman of the Fed. Reserve, At the Federal Reserve Bank of Chicago's 42nd Annual Conference on Bank Structure and Competition (May 18, 2006), https://www.federalreserve.gov/newsevents/speech/bernanke20060518a.htm [https://perma.cc/M6AA-7TMT], in BD. OF GOVERNORS OF THE FED. RESERVE SYS. [FeD. Reserve BD. Of Governors], Basel II: Its Promise and Its Challenges.

9 U.S. DeP'T OF the Treasury, Blueprint for a Modernized Financial REGULATORY STRUCTURE 27 (2008), https:// www.treasury.gov/press-center/pressreleases/Documents/Blueprint.pdf [https://perma.cc/4WVJ-9XUH].
} 
Tarullo, one of Obama's campaign advisors ${ }^{10}$ and President Clinton's assistant for international economic policy, ${ }^{11}$ wrote that the "tortured negotiations" over Basel II had kept U.S. regulators from addressing the very risks that torpedoed Bear Stearns. ${ }^{12}$ Without discounting cooperation entirely, he wrote, "something different must be tried." 13

Surprisingly, Obama's victory that fall ushered in victories for both believers and skeptics of international regulatory coordination. After the crisis, as a member of the Basel Committee ${ }^{14}$ and Financial Action Task Force, ${ }^{15}$ the United States engaged actively in the creation of new international standards ${ }^{16}$ for bank capital, ${ }^{17}$ liquidity, ${ }^{18}$

10 Joanna Klonsky, Foreign Policy Brain Trusts: Obama's Advisers, CounCIL ON FOREIGN REL. (Nov. 11, 2008), https:/ / www.cfr.org/backgrounder/foreign-policybrain-trusts-obamas-advisers [https://perma.cc/5G24-MZUR].

11 Fed. Reserve Bd. of Governors, Daniel K. Tarullo, [hereinafter Tarullo Biography] https://www.federalreservehistory.org/people/daniel_k_tarullo [https:/ / perma.cc/5GL9-2XSL] (last visited Feb. 7, 2018).

12 Daniel Tarullo, Banking on Basel 9 (2008).

$13 \mathrm{Id}$. at 284.

14 Bank for Int'1 Settlements [BIS], Basel Committee Membership, (Dec. 30, 2016), https://www.bis.org/bcbs/membership.htm [https://perma.cc/W2WQ-BMUY].

15 Financial Action Task Force [FATF], FATF Members and Observers: The 37 Members of FATF [hereinafter FATF, Members and Observers], http://www.fatfgafi.org/about/membersandobservers [https://perma.cc/H8CS-2Z2A] (last visited Feb. 7, 2018).

16 See, e.g., BIS, Basel III: International Regulatory Framework for Banks, https://www.bis.org/bcbs/basel3.htm [https://perma.cc/W4GY-WFX4] (last visited Feb. 7, 2018) (providing overview of the Basel III framework).

17 See, e.g., BASEL COMM. ON BANKING SuPERVISION, BASEL III DEFINITION OF CAPITAL - FREQUENTLY ASKED Questions (BIS 2011), https://www.bis.org/publ/bcbs198.pdf [https://perma.cc/5GHN-X26U].

18 See, e.g., BIS, Basel III: The Liquidity Coverage Ratio and Liquidity Risk Monitoring Tools, https://www.bis.org/publ/bcbs238.htm [https://perma.cc/4N5DZ3S7], (last visited Feb. 7, 2018) ("The LCR was first published in December 2010. At that time, the Basel Committee put in place a rigorous process to review the standard and its implications for financial markets, credit extension and economic growth."). 
risk management, ${ }^{19}$ governance, ${ }^{20}$ and the prevention of money laundering and the financing of terrorism. ${ }^{21}$ However, federal policymakers also began to express new skepticism towards the work of foreign financial regulators. Beginning with the Dodd-Frank Wall Street Reform and Consumer Protection Act ("Dodd-Frank"), 22 they ratified policies that exposed the U.S. affiliates of foreign banks to stricter treatment on American shores. These trends were not restricted to certain branches of government, nor to certain areas of financial regulation, but coexisted across U.S. policy, even within the same piece of legislation.

This Comment attempts to explain how America could, ostensibly, both jealously guard and willingly cede control over the rules that governed its financial system. America's renewed commitment to international engagement was consistent with rational institutionalism, particularly with Robert Keohane's "demand-side" account of international regimes. ${ }^{23}$ Keohane argued that the "anarchy" and "pervasive uncertainty" of a world without global government create transaction costs, which prevent nations from engaging in coordinated, "mutually beneficial" behavior. ${ }^{24}$ International institutions lower those transaction costs - for example, by creating legal commitments (and with them, liability) or easing the acquisition of information; institutions allow nations to make

\footnotetext{
19 See, e.g., BASEl Comm. ON BANKING Supervision, Consultative Document: Strengthening the Resilience OF THE BANKING Sector (BIS 2009), https://www.bis.org/publ/bcbs164.pdf [https://perma.cc/39VR-7NLG]. The BIS published numerous documents on risk management, including capital planning, market risk, counterparty credit risk, and compensation. See generally BIS, Basel Committee - Risk Management, https://www.bis.org/list/bcbs/tid_50/index.htm [https:/ / perma.cc/WYG3-D6T7] (last visited Feb. 7, 2018).

$\begin{array}{ccccc}20 & \text { See, e.g., BASEl COMM. ON BANKING SUPERVISION, COMPENSATION PRINCIPLES } \\ \text { AND STANDARDS ASSESSMENT METHODOLOGY (BIS 2010), }\end{array}$ https://www.bis.org/publ/bcbs166.pdf [https:/ / perma.cc/V7PL-BQWL].

21 See FATF, International Standards on Combatting Money Laundering and the Financing of Terrorism and Proliferation: The FATF Recommendations (Feb. 2012) [hereinafter FATF, International Standards], http://www.fatf-gafi.org/media/fatf/documents/recommendations/pdfs/fatf_recommendations.pdf [https://perma.cc/K3HK-LHL6].

22 Dodd-Frank Wall Street Reform and Consumer Protection Act of 2009, Pub. L. No. 111-203, § 929-Z, 124 Stat. 1376 (2010) (codified as 12 U.S.C. § 53o).

23 See Robert O. Keohane, The Demand for International Regimes, 36 INT'L ORG. 325 (1982).

24 Id. at 332.
} 
agreements that would otherwise be "impossible to consummate." 25 Many of the institutions Obama mentioned in his Cooper Union speech were designed with such a purpose in mind-for example, the Basel Committee, formed in response to United States and EU spillovers from the failure of Herstatt Bank in Cologne, and the Financial Stability Forum, formed in the wake of the 1998 turbulence in Asian capital markets. ${ }^{26}$ The 2008 crisis revealed more and greater external transaction costs, which had kept countries from cooperating effectively to oversee their financial institutions. Under this view, recommitting to Basel was a way to internalize and reduce these costs.

However, the demand-side account provides a less satisfying explanation of America's post-crisis domestic financial regulations. Though they generally create no binding international legal obligations, regulatory fora like the Basel Committee are premised on mutual trust; participating countries agree to implement policy on the condition that their peers do so as well. ${ }^{27}$ However, Dodd-Frank's heightened prudential standards, ${ }^{28}$ restrictions on IMF support, ${ }^{29}$ and novel supervisory authority over foreign nonbanks ${ }^{30}$ were not contingent measures; they applied even if a foreign country's bank supervisor lived up to international norms. In short, the United States was not simply a unified rational actor "hedging its bets" on the international stage using domestic policy; the country's actions seemed to both preclude and assume the possibility its allies would defect and "under-regulate" their financial institutions.

To explain this concurrence of cooperation and defection, one must instead look to domestic politics - not just electoral, but also institutional and individual. Public attention to the details of regulatory reform was scant, especially as Congress considered other

${ }^{25} \mathrm{Id}$. at 334 .

26 See Christopher Brummer, Minilateralism: How Trade Alliances, Soft LAW AND FinANCIAL ENGINEERING ARE REDEFINING ECONOMIC STATECRAFT 99, 102 (2014).

27 See BIS, Basel Committee Charter, (Dec. 30, 2016), https://www.bis.org/bcbs/charter.htm [https://perma.cc/8NPM-5JKX] ("The BCBS ['Basel Committee on Banking Supervision'] sets standards for the prudential regulation and supervision of banks. The BCBS expects full implementation of its standards by BCBS members and their internationally active banks.").

2812 U.S.C. $\S 5365$ (2012).

2922 U.S.C. § 286tt (2012).

3012 U.S.C. § 5322 (2012). 
pieces of contentious legislation. In this environment, the divergent preferences of actors in different parts of government-some favoring more international cooperation, others opposing it-became more important to both domestic legal outcomes and U.S. conduct abroad. American regulation of foreign financial institutions serves as a case study in how municipal dynamics can shape international relations, one that may shed light on other countries during the 2008 financial crisis and on the United States during previous ones. ${ }^{31}$ In financial regulatory matters, it seems, politics rarely stops at the water's edge. ${ }^{32}$

This Comment briefly reviews relevant U.S. banking law from before, during, and after the 2008 financial crisis, focusing on the provisions that govern foreign financial companies operating within the United States. This law is less important than the story of the institutions that shaped it, and the Author has structured this Comment accordingly. The research was also inevitably influenced by what followed Dodd-Frank's passage: the adoption of a 2014 Federal Reserve rule requiring foreign banking organizations to reorganize their domestic operations under intermediate holding companies. ${ }^{33}$ Although Dodd-Frank did not require such a rule and

31 For example, in 2014, the new Prudential Regulation Authority said that it would require institution-specific agreements with home supervisors for every foreign-bank branch in the U.K., or would otherwise require those branches to become subsidiaries, subject to their own capital and liquidity requirements. See, e.g., Kai Kohlberger \& John Andrews, Foreign Bank Branches in the U.K.: The PRA Approach, DeloitTE: FinANCIAL SERVICES U.K. (Feb. 26, 2014), http://blogs.deloitte.co.uk/financialservices/2014/02/foreign-bank-branches-in-the-uk-the-pra-approach.html [https://perma.cc/PT9J-U2UQ]. It is also notable that the Basel I accord was agreed at roughly the same time as the passage of the International Banking Act of 1978 in the United States. See Bush, infra note 35 and accompanying text.

32 Christopher Brummer explored the idea of territoriality as an instrument of extraterritorial regulation in a 2011 article, noting-without reference to DoddFrank - that territorial jurisdiction remained a potent tool in regulating capital markets. See Christopher Brummer, Territoriality as a Regulatory Technique: Notes from the Financial Crisis, 79 U. CIN. L. REV. 499 (2011), https://scholarship.law.uc.edu/cgi/viewcontent.cgi?article $=1031 \&$ context $=$ uclr

[https://perma.cc/Q69U-P34B] (building on his core observations by adding both empirical information on post-crisis U.S. policy and by contextualizing this regulatory dynamic in international relations theory).

33 See Fed. Reserve Bd. of Governors, Federal Reserve Board Approves Final Rule Strengthening Supervision and Regulation of Large U.S. Bank Holding Companies and Foreign Banking Organizations, (Feb. 18, 2014), https://www.federalreserve.gov/newsevents/press/bcreg/20140218a.htm [https://perma.cc/2TXAAY3W]. 
although Congress urged the Federal Reserve to give "due regard to the principle of national treatment and equality of competitive opportunity" in foreign-bank rulemakings ${ }^{34}$-some have argued that the rule imposes a subsidiarization requirement on foreign-owned U.S. banks. ${ }^{35}$ The Author take no position on this interpretation, and it falls outside the time period and thus the scope of this Comment; however, the possibility of it emerged much earlier, and its spirit animated the final text of the bill.

\section{BACKGROUND: U.S. DOMESTIC REGULATION OF FOREIGN BANKING ORGANIZATIONS}

To operate in the United States, commercial banking organizations must meet two broad requirements, regardless of the nationality of their ultimate parent: First, they must secure and maintain a charter; second, they must abide by the laws and regulations to which their charter subjects them. ${ }^{36}$ Over time, these requirements have shaped both commercial opportunities for foreign financial institutions in the United States and foreign access to the U.S. financial system. ${ }^{37}$

Under the U.S. "dual banking system," banks may opt to apply for either a state or federal charter. ${ }^{38}$ Federally chartered banking

34 Enhanced Prudential Standards and Early Remediation Requirements for Foreign Banking Organizations and Foreign Nonbank Financial Companies, 77 Fed. Reg. 76,628 (Dec. 28, 2012) (to be codified at 12 C.F.R. pt. 252), https://www.gpo.gov/fdsys/pkg/FR-2012-12-28/pdf/2012-30734.pdf [https://perma.cc/Y7MS-PYCE].

35 See, e.g., Derek M. Bush, A Dramatic Departure? National Treatment of Foreign Banks, THE ClEARING House (2015), https://www.theclearinghouse.org/bankingperspectives/2015/2015-q1-banking-perspectives/articles/national-treatment-offoreign-banks [https://perma.cc/S3ET-JZ2M].

36 See, e.g., Fed. Reserve Bd. of Governors, FAQ: How Can I Start a Bank?, (Aug. 2, 2013), https://www.federalreserve.gov/faqs/banking_12779.htm [https://perma.cc/X59T-M4PC].

37 See BRUMMER, supra note 26.

38 See, e.g., Esther L. George, President \& CEO of the Fed. Reserve Bank of Kansas City, Conference of State Bank Supervisors (May 22, 2012), https://www.kansascityfed.org/publicat/speeches/2012-george-ga-csbs-0522.pdf [https:// perma.cc/8LEB-2CW8], in Perspectives on 150 Years of Dual Banking; Heidi Mandanis Schooner, Recent Challenges to the Persistent Dual Banking System, 41 
organizations are subject to regulations by at least one federal prudential regulator. "National banks," for example, are regulated by the Office of the Comptroller of the Currency ("OCC") ${ }^{39}$; "bank holding companies," "financial holding companies," and Edge Act corporations are regulated by the Board of Governors of the Federal Reserve ("Federal Reserve") and examined by regional banks of the Federal Reserve System. 40

Federally chartered banking organizations must also obtain federal deposit insurance and follow the regulations of the Federal Deposit Insurance Corporation ("FDIC"). ${ }^{41}$ By contrast, state-chartered banking organizations are regulated by state banking authorities. However, most states require their banks to obtain federal deposit insurance, ${ }^{42}$ and state-chartered banks may join the Federal Reserve System. ${ }^{43}$ As a result, many state-chartered banks are also subject to FDIC and Federal Reserve oversight. ${ }^{44}$

ST. LoUIS U. L. J. 263 (1996), http:/ / scholarship.law.edu/cgi/viewcontent.cgi?article=1262\&context=scholar [https: / / perma.cc $/ 2 Z Z X-M W T A]$.

${ }^{39}$ Office of the Comptroller of the Currency [OCC], U.S. Dep't of the Treasury, National Banks and Federal Savings Associations Lists, (Nov. 30, 2016), https://www.occ.treas.gov/topics/licensing/national-banks-fed-savings-assoclists/index-active-bank-lists.html [https:/ / perma.cc/LKU6-GD7F].

40 Fed. Reserve Bd. OF Governors, Financial Holding Company Election (2014), https://www.federalreserve.gov/bankinforeg/afi/fhcfilings.htm [https://perma.cc/9SSU-UEAQ]; FED. RESERVE BD. OF GOVERNORS, BANK HOLDING COMPANY SUPERVISION MANUAL \& 1030-40 (2016), https://www.federalreserve.gov/publications/files/1000.pdf [https://perma.cc/BM98-CM7J]; Fed. Reserve Bd. of Governors, FAQ: How is the Federal Reserve System Structured?, (Aug. 17, 2016), https://www.federalreserve.gov/faqs/about_12593.htm [https://perma.cc/5QES-5BTS].

41 Fed. Deposit INs. CoRP. [FDIC], 2015-2019 Strategic Plan, (May 19, 2015), https://www.fdic.gov/about/strategic/strategic/bankingindustry.html [https://perma.cc/2RU2-QMX6], superseded by FDIC, 2018-2022 Strategic Plan, (Jan. 1, 2018).

42 John C. Dugan et al., FDIC Insurance and Regulation of U.S. Branches of Foreign Banks, in REgUlATION OF FOREIGN BANKS AND AFFILIATES IN THE UNITED STATES 606 n.2 (Randall D. Guynn ed., 8th ed. 2014).

43 See, e.g., Fed. Reserve Bank of Richmond, Federal Reserve Membership, https://www.richmondfed.org/banking/federal_reserve_membership [https://perma.cc/FUU6-C2QE] (last visited Feb. 7, 2018).

44 This description omits federal regulation by "functional regulatory agencies, such as the Securities and Exchange Commission, the Commodity Futures Exchange Commission, and since 2010, the Consumer Financial Protection Bureau ("CFPB"). 
Foreign banks have long operated in the United States through a mix of distinct entity forms, each of which faces different limitations on its funding and operations. ${ }^{45}$ Branch offices of U.S. banks can accept deposits and make loans on behalf of a foreign bank; branches do not need to raise separate capital from their parent bank by issuing equity or debt or meet separate capital requirements, such as holding a certain proportion of equity to other instruments. ${ }^{46}$ By contrast, foreign bank subsidiaries must be separately capitalized. ${ }^{47}$ Bankers sometimes argue that such capital requirements are "expensive," while regulators sometimes argue that the requirements improve investor oversight and make institutions more resilient, reducing the expected costs. 48

Until 1978, foreign banking organizations and U.S. banks owned by a foreign financial institution were ineligible for federal charters or federal deposit insurance. A foreign bank that wished to operate in the United States had to obtain a state charter, and states regulated much of their activity.49 However, in the wake of the 1974 failures of Herstatt and Franklin National Bank, Congress passed the International Banking Act ("IBA"), which subjected foreign bank branches to the same Federal Reserve regulations and supervision as U.S. bank holding companies. 50

Under the "source of strength" doctrine, which the Federal Reserve successfully applied under the Bank Holding Company Act, foreign banks were effectively required to support-with both financial and managerial resources-the operations of their U.S. branches. ${ }^{51}$ The IBA also established the principle of "national

45 James V. Haupt, Div. OF Banking Supervision AND Regulation, INTERNATIONAL ACTIVITIES OF U.S. BANKS AND IN U.S. BANKING MARKETS, FED. ReS. Bull. 599-601 (1999), https://www.federalreserve.gov/pubs/bulletin/1999/0999lead.pdf [https://perma.cc/5HF9-UVMX].

${ }^{46} I d$. A foreign bank may also open a "representative office" that can direct business towards its foreign parent but may not take deposits or make loans.

$47 \mathrm{Id}$.

48 William Alden, What Is Bank Capital, Anyway?, N.Y. Times (July 10, 2013), http://dealbook.nytimes.com/2013/07/10/what-is-bank-capital-anyway/ [https://perma.cc/2B9M-3HL4].

49 Dugan et al., supra note 42, at 606.

50 See Bush, supra note 35.

51 For a history of the doctrine, see Craig L. Brown, Board of Governors v. MCorp Financial, Inc.: Evaluating the Source-of-Strength Doctrine, 21 HOFSTRA L. REV. 235, 236 (1992), http://scholarlycommons.law.hofstra.edu/cgi/viewcontent.cgi?article=1852\&context=hlr [https:/ / perma.cc/J4TP-AH2V]. 
treatment and equality of competitive opportunity," allowing foreign banks to obtain national charters from the OCC and deposit insurance from the FDIC. 52

Foreign banks faced more stringent federal regulations after a wave of late-1980s financial panics, including a scandal involving the Bank of Commerce Credit International ("BCCI") and Banca Nazionale de Lavoro. ${ }^{53}$ Passed in 1991, the Foreign Bank Supervision Enhancement Act ("FBSEA") required the Federal Reserve to approve any new foreign bank branches and decide whether a foreign bank's home country subjected its parent to "comprehensive consolidated supervision." 54 For the first time, federal regulators had to assess the conduct of regulatory agencies in foreign countries, before letting a company from that foreign country operate in the United States. Federal regulators have entered into "information-sharing memoranda of understanding" with foreign regulatory agencies, including those in Dubai ${ }^{55}$ and the U.K., ${ }^{56}$ to help satisfy this requirement. 57

52 See Frank Anthony Misuraca, Foreign Banking in the United States: An Objective Study of the International Banking Act of 1978, 4 J. INT'L L. \& PRAC. 539, 542-43 (1995).

53 See, e.g., Steve Lohr, World-Class Fraud: How B.C.C.I. Pulled It Off - A Special Report; At the End of a Twisted Trail, Piggy Bank for a Favored Few, N.Y. TIMES (Aug. 12, 1991), http://www.nytimes.com/1991/08/12/business/world-class-fraudbcci-pulled-it-off-special-report-end-twisted-trail-piggy-bank.html [https:/ / perma.cc/6HBA-9SWB]; 137 CONG. REC. 25,2662 (1991) (statement of Rep. Riggs on financial reform and "the BCCI affair").

54 Fed Reserve BD. OF GOVERNORS, SR 08-9/CA 08-12, CONSOlidATED SuPERVISION OF BANK HOLDING COMPANIES AND THE COMBINED U.S. OPERATIONS OF Foreign BANKING ORganizations: ATtACHMENT C - Definition of KEY TERMS (2008), https://www.federalreserve.gov/boarddocs/srletters/2008/sr0809c.pdf [https://perma.cc/B5D6-9Q39].

55 DFSA Enters into MOU with United States Banking Supervisors, MIDDLE EAST NEWs SERV. (Oct. 24, 2007), https://advance.lexis.com/api/permalink/e107b545f631-422b-a528-8860dacd42c7/?context=1000516 [https://perma.cc/8KHWL3SM].

56 Angela Hayes \& Charles Horn, FDIC and FSA Sign Agreement to Increase Cooperative Cross-Border Framework for Emergency Planning and Action, MONDAQ Bus. BRIEFING (July 10, 2008), https://advance.lexis.com/api/permalink/dce64a03802f-4ec0-b06f-4446f3f961e2/ ?context=1000516 [https:/ / perma.cc/2ZGH-6EC6].

57 See The Future of Bank Examination and Supervision: Hearing Before the House Committee on Banking And Financial Services Subcommittee on Financial Institutions $\mathcal{E}$ Consumer Credit, 105th Cong. (1997) (statement of Andrew C. Hove, Jr., Acting Chairman, Federal Deposit Insurance Corporation), https://advance.lexis.com/api/permalink/eefc1ef9-de08-42fe-ba67- 
The FBSEA also required the Treasury Department to study the idea of only allowing foreign banks to operate in the United States through subsidiaries (holding their own capital) instead of branches (without holding their own capital). However, Treasury rejected this idea, worrying that "foreign countries might also retaliate against U.S. bank branches, perhaps by requiring that they establish a subsidiary or by otherwise restricting their activities." 58

Instead, over this same thirty year period, the United States participated in the creation of standards for banking oversight through the Basel Committee on Banking Supervision ("Basel Committee"), a convening of G10 central bankers and bank regulators that began in 1974.59 The Committee began by issuing a non-binding accord on the definition and appropriate levels of bank capital, then crafted increasingly complex standards on cross-border regulation, the use of private banking risk models, and risk management. ${ }^{60}$ The second iteration of the Basel Framework (Basel II) was released in 2006.61

\section{THE 2008 FINANCIAL CRISIS: TRANSACTION COSTS AND COSTLY TRANSACTIONS}

The United States was in the process of implementing the risk-measurement provisions of Basel II when disruption in the mortgage market sparked the 2008 financial crisis. ${ }^{62}$ The crisis

\footnotetext{
f6a3b5c6ceeb/?context=1000516 [https://perma.cc/RZM5-63S2] ("The FDIC has pursued, both bilaterally and with the other federal banking agencies, informationsharing agreements with foreign supervisors.").

58 Treasury-Fed Study Backs U.S. Branches of Foreign Banks, BANKING POL'Y REP. 8 (1993).

59 BIS, History of the Basel Committee, (Apr. 14, 2018), http://www.bis.org/bcbs/history.pdf [https:// perma.cc/7PUP-UNTX].

$60 \mathrm{Id}$.

61 See BASEL COMM. ON BANKING SUPERVISION, INTERNATIONAL CONVERGENCE OF Capital Measurement and Capital Standards: A Revised Framework COMPREHENSIVE VERSION (2006), https://www.bis.org/publ/bcbs128.pdf [https://perma.cc/8HEL-583Y].

62 See, e.g., Risk-Based Capital Standards: Advanced Capital Adequacy Framework-Basel II, 72 Fed. Reg. 69288 (Dec. 7, 2007) (to be codified at 12 C.F.R. pt. 3) [https://perma.cc/G5E9-PSDS].
} 
revealed two substantial problems that were specific to foreign banks operating in the United States, which Basel II did not address.

The first problem involved Lehman Brothers and demonstrated the risk of relying on capital held overseas for the stability of U.S. banking operations. The 158-year-old investment bank teetered on the brink of collapse in September 2008, when Treasury Secretary Henry Paulson, New York Federal Reserve President Timothy Geithner, and Securities and Exchange Commission ("SEC") Chairman Christopher Cox brokered a tentative acquisition by the U.K.based bank Barclays plc. ${ }^{63}$ However, with commitments from both Lehman and Barclays in place, Barclays' regulator, the U.K. Financial Services Agency (FSA), refused to approve the deal without notice to Barclays' shareholders or greater assurances about Lehman's solvency. ${ }^{64}$ Shareholder notice alone would require a long enough delay to virtually guarantee Lehman's collapse. After a call with U.K. FSA Chairman Callum McCarthy, Treasury Secretary Paulson ruefully told a room full of CEOs of large banks who had agreed to support the deal, "[the British] grin-f**ed us." One CEO retorted: "Isn't this our closest ally in the world?" 65

The second problem was the byproduct of a successful U.S. strategy to stanch financial panic. One of the largest risks to the U.S. financial system came from American International Group ("AIG"), a multi-line insurance company that underwrote credit-default swaps ("CDS"), which guaranteed large private financial institutions against losses on mortgage-backed securities. ${ }^{66}$ As those losses began to mount, AIG itself began to falter, and the possibility of its failure to pay amounts due on those swaps imperiled the solvency of major U.S. financial institutions. ${ }^{67}$ To avoid catastrophe, the U.S. government offered AIG an $\$ 85$ billion loan facility in exchange for

63 James B. Stewart, Eight Days, THE New Yorker (Sept. 21, 2009), http://www.newyorker.com/magazine/2009/09/21/eight-days

[https:// perma.cc/X6DQ-G9YX] (discussing the role of various political players in the financial crisis).

64 Andrew Ross Sorkin, ToO Big to Fail: The Inside Story of How Wall STREET AND WASHINGTON FOUGHT TO SAVE THE FINANCIAL SYSTEM - AND THEMSELVES 343-45 (2010).

$65 \mathrm{Id}$. at 350.

66 Adam Davidson, How Lehman Fell Apart, ReUTERs (Sept. 18, 2008), http:/ / www.reuters.com/article/us-how-aig-fell-apartidUSMAR85972720080918 [https:/ / perma.cc/Q26V-QZLY].

$67 \mathrm{Id}$. 
a controlling stake in the company. 68 However, AIG's exposures were global, not just domestic, meaning that support from U.S. taxpayers helped AIG honor its obligations to foreign financial institutions. ${ }^{69}$

Supporting AIG - and its overseas counterparties - came at a steep political cost. Federal Reserve skeptics claimed that the government had used trillions in taxpayer funds to support foreigners, 70 a claim that appeared more egregious when AIG and other recipients of federal support paid out hundreds of millions of dollars in bonuses.71 Worse still, press outlets often reported the Federal Reserve's gross extensions as if they were net figures, making the support offered by U.S. taxpayers seem even larger. ${ }^{72}$ To critics, foreign banks had not been a source of strength to the United States; rather, the United States had been a source of strength to foreign banks.

68 Matthew Karnitschnig et al., U.S. to Take Over AIG in \$85 Billion Bailout; Central Banks Inject Cash as Credit Dries Up, WALL ST. J. (Sep. 16, 2008), http://www.wsj.com/articles/SB122156561931242905 [https://perma.cc/42TC4YBE].

${ }^{69}$ Mary Williams Walsh, A.I.G. Lists Banks it Paid with U.S. Bailout Funds, N.Y. TIMES (Mar. 15, 2009), http://www.nytimes.com/2009/03/16/business/16rescue.html [https:/ / perma.cc/FE3P-SKU7].

70 See, e.g., Associated Press, Fed Reveals which Banks, Companies got Trillions in Emergency Bailout, Including McDonald's, N.Y. DAILY NeWs, (Dec. 1, 2010), http://www.nydailynews.com/news/money/fed-reveals-banks-companies-trillions-emergency-bailout-including-mcdonald-article-1.473798

[https://perma.cc/ZYN6-27W7]; Tracey Greenstein, The Fed's \$16 Trillion Bailouts Under-Reported, FORBES (Sep. 20, 2011), http://www.forbes.com/sites/traceygreenstein/2011/09/20/the-feds-16-trillionbailouts-under-reported [https://perma.cc/5Z9C-B3WP]; Sewell Chan, From Tea Party Advocates, Anger at the Federal Reserve, N.Y. TIMES (Oct. 10, 2010), http:/ /www.nytimes.com/2010/10/11/us/politics/11fed.html

[https://perma.cc/EAR6-23QL].

71 Eamon Javers, AIG Ships Billions in Bailout Abroad, POLITICO (Mar. 16, 2009), http:/ / www.politico.com/story/2009/03/aig-ships-billions-in-bailout-abroad020039 [https://perma.cc/V248-XH4Z].

72 See, e.g., Jon Greenberg, Did the Fed Create $\$ 15$ Trillion During the Bailout and Send \$5 Trillion Overseas?, POLITIFACT (Dec. 9, 2011), http://www.politifact.com/truth-o-meter/statements/2011/dec/09/ron-paul/did-fed-create-15trillion-during-bailout-and-send [https://perma.cc/Q84C-BXTE]. 


\section{UNITED STATES PARTICIPATION IN INTERNATIONAL POST-CRISIS FINANCIAL REGULATORY MEASURES}

Despite this early backlash, much of the initial United States response to the financial crisis was multilateral and international. By August 2009, the Federal Reserve had extended temporary bilateral credit lines to fourteen other central banks, in order to maintain liquidity in foreign currency markets. ${ }^{73}$ In September 2009, a meeting of G20 leaders produced a list of specific commitments each country would make to advance financial reform. ${ }^{74}$ To enforce these commitments, the G20 converted the Financial Stability Forum into the Financial Stability Board ("FSB"), a clearinghouse to oversee the largest global financial institutions and exchange information on system-wide financial risks. ${ }^{75}$ The FSB began to monitor compliance with Basel Committee standards, and starting in 2010, the Basel Committee itself began to publish revised standards for bank oversight. ${ }^{76}$ The United States also redoubled its commitment to the Financial Action Task Force ("FATF"), a group of thirty-five states and international organizations established in 1989 to coordinate antimoney laundering and counter-the-financing-of-terrorism (AML/CFT) policy.77 FATF issued a more stringent set of non-binding "recommendations" in 2012 and facilitated a set of peer reviews

73 Fed. Reserve BD. Of Governors, Credit and Liquidity Programs And the BALANCE SHEET: CENTRAL BANK LIQUidity SwAPS, (2017), https://www.federalreserve.gov/monetarypolicy/bst_liquidityswaps.htm [https://perma.cc/2C5T$\mathrm{XBHQ}$.

74 Office of the Press Sec., Exec. Office of the President, G-20: Fact Sheet ON U.S. FinANCIAL REFORM AND THE G-20 LEADERS' AgENDA (2011), https:/ /obamawhitehouse.archives.gov/the-press-office/2011/11/04/g-20-factsheet-us-financial-reform-and-g-20-leaders-agenda [https://perma.cc/8NYTYPP4].

75 Elena Moya, Financial Stability Board: How It Will Work, THE GuARDIAN (Apr. 3, 2009), https://www.theguardian.com/world/2009/apr/04/financial-stabilityboard-g20 [https:/ / perma.cc/9Y76-A6QA].

76 Huberto M. Ennis \& David A. Price, Fed. Reserve Bank of Richmond, EB11-06, BASEl III AND THE CONTINUING EVOLUTION OF BANK CAPITAL REGULATION (2011), https://www.richmondfed.org/ /media/richmondfedorg/publications/research/economic_brief/2011/pdf/eb_11-06.pdf

[https://perma.cc/V6NB-KLRV]; Financial Stability Board [FSB], Basel III - Implementation, http://www.fsb.org/basel-iii [https://perma.cc/P7AK-3DE8] (last visited Jan. 26, 2018).

77 FATF, Members and Observers, supra note 15. 
between its members' finance ministries. ${ }^{78}$ Finally, even in its own domestic activities, the United States showed deference to foreign regulators - for example, limiting its initial stress-testing program to U.S. companies, even though two of the ten largest financial institutions in the United States were owned by foreign banks. ${ }^{79}$

These initial international steps had several traits in common. First, as with previous Basel capital accords, they gained the wholehearted support of the G20, but they remained formally nonbinding. Second, enforcement mechanisms were limited to reputational costs; the FSB and FATF would "name and shame" countries that failed to honor their commitments, but they could impose no other formal sanctions.

Third, senior officials in the executive branch retained almost complete discretion over U.S. consent to these measures. The Undersecretary of the Treasury for International Finance held responsibility for representing the United States in G7 and G20 discussions under many of its recent officeholders, including John Taylor, 80 Timothy Adams, 81 David Mulford, 82 and, under President Obama, Lael

78 FATF, International Standards, supra note 21.

79 See Fed. Reserve BD. OF Governors, The Supervisory CAPITAL Assessment Program: OVERVIEW OF RESUlts (2009), https://www.federalreserve.gov/newsevents/press/bcreg/bcreg20090507a1.pdf

[https://perma.cc/3AX7-V7R2]. The two foreign institutions in question, based on 1Q09 FDIC call report data, were HSBC North America Holdings and Barclays Group U.S.

80 See Stanford Ctr. on Global Poverty on Dev., John B. Taylor, STANFORD UnIV., https://globalpoverty.stanford.edu/people/john-b-taylor [https:/ / perma.cc/7RWQ-WGZ8] (last visited Jan. 26, 2018) (“Taylor served as Under Secretary of Treasury for International Affairs where he was responsible for... coordinating financial policy with the G-7 countries").

81 See Inst. of Int'1 Fin. [IFF], IFF Leadership: Timothy D. Adams, President and CEO, https://www.iif.com/leadership [https:/ / perma.cc/26QP-BWLW] (last visited Jan. 26, 2018) ("Previously, [Adams] served as Under Secretary of Treasury for International Affairs... [and] was the Administration's point person on international financial issues, including exchange rate policy, G-7 meetings, and IMF and World Bank issues.").

82 See Credit Suisse Appoints Ambassador David Mulford Vice-Chairman International, BUSINESS WIRE (Mar. 11, 2009), https://www.businesswire.com/news/home/20090311006307/en/Credit-Suisse-Appoints-Ambassador-David-Mulford-Vice-Chairman [https://perma.cc/5B4E-KFER] ("Ambassador Mulford also previously served in the [U.S.] Government as Under Secretary and Assistant Secretary of the [U.S.] Treasury for International Affairs. . . . [where] he played a key role representing the [U.S.] Government on a number of issues, including coordinating economic policy with the G-7."). 
Brainard.83 Treasury's Office of Terrorist Financing and Financial Crimes has long represented the United States to FATF. ${ }^{84}$ The Federal Reserve, OCC, and FDIC have long represented the United States in Basel and FSB activities. ${ }^{85}$ Beyond overseeing and confirming the leaders of these agencies - and, in the case of the U.S. Treasury, appropriating its operating funds - the roles of Congress and the courts remained relatively limited. ${ }^{86}$

Leaders of the U.S. executive branch were not shy about their support for increased international cooperation. In closing the G20 Pittsburgh Summit, President Obama said that since "the nations of the world share mutual interests," the G20 countries must inaugurate "a new era of engagement ... and act on behalf of our shared security and prosperity." 87 Bernanke, who remained Federal Reserve Chairman under Obama, agreed with this sentiment publicly, calling it "self-evident that, in light of the global nature of financial institutions and markets, the reform of financial regulation and supervision should be coordinated internationally to the greatest extent possible." 88 Geithner did the same, telling an IMF audience that

83 See Fed. Reserve Bd. of Governors, Board Members: Lael Brainard (Oct. 19, 2017), https://www.federalreserve.gov/aboutthefed/bios/board/brainard.htm [https:/ / perma.cc/5B78-JG3C] ("Dr. Brainard served as Undersecretary of the U.S. Department of Treasury from 2010 to 2013 and Counselor to the Secretary of the Treasury in 2009. During this time, she was the U.S. Representative to the G-20 Finance Deputies and G-7 Deputies and was a member of the Financial Stability Board.").

84 See U.S. Dep't of the Treasury, U.S. Delegation Participates in Financial Action Task Force Plenary (June 21, 2013), https://www.treasury.gov/press-center/pressreleases/Pages/j11989.aspx [https://perma.cc/Q6RM-D65F]; Sabina Kook, U.S. Dep't of the Treasury, Treasury Notes: Financial Action Task Force (FATF) Evolving in its Effort to Combat Money Laundering and Terrorist Financing (Mar. 27, 2013), https://www.treasury.gov/connect/blog/Pages/Financial-Action-Task-Force(FATF)-Evolving-in-its-Effort-to-Combat-Money-Laundering-and-TerroristFinancing.aspx [https://perma.cc/8TCW-D3TF].

85 BIS, Basel Committee Membership, supra note 14.

86 See, e.g., Brooksley Born \& William Donaldson, Make Regulators Self-Funding, Politico (Mar. 10, 2013), http://www.politico.com/story/2013/03/self-fundingof-regulators-would-help-fiscal-mess-088666 [https://perma.cc/9E96-9JPU].

87 President Barack Obama, The President Addresses the Press on G-20 Summit (Sept. 25, 2009), https://obamawhitehouse.archives.gov/realitycheck/video/The-PresidentAddresses-the-Press-on-G-20-Summit?tid=101\#transcript [https:/ / perma.cc/E8HS-CQ3F].

88 Ben S. Bernanke, Chairman of the Fed. Reserve, Speech the Federal Reserve Bank of Kansas City's Annual Economic Forum, Jackson Hole, Wyoming: 
its response to the crisis must be "quick, forceful, and global in nature." 89

In their respective memoirs, Geithner and Bernanke also supported internationalism - in order to preserve U.S. competitiveness. "Without international coordination," Bernanke wrote:

tougher domestic regulation might result only in banking activity moving out of the United States to foreign financial centers. Moreover, even if foreign jurisdictions adopted comparably tough rules, in the absence of international coordination those rules might be inconsistent with U.S. standards, which could fragment global capital markets and otherwise diminish the effectiveness of new rules. 90

Geithner struck a similar note in 2014: "If we had unilaterally imposed strict new limits on risk, without encouraging higher standards globally, we simply would have reduced the market share of U.S. firms around the world, without making the global system more resilient." 91

The close alignment of these two perspectives - one at the helm of the Federal Reserve, the other at the Treasury - was not lost on

Reflections on a Year of Crisis (Aug. 21, 2009), https://www.federalreserve.gov/newsevents/speech/bernanke20090821a.htm

[https://perma.cc/ML9P-ARNA]; see also Ben S. Bernanke, Chairman of the Fed. Reserve, Speech at the Stamp Lecture, London School of Economics, London, England: The Crisis and the Policy Response, (Jan. 13, 2009), https://www.federalreserve.gov/newsevents/speech/bernanke20090113a.htm

[https://perma.cc/3XUR-Q6MH] ("Finally, a clear lesson of the recent period is that the world is too interconnected for nations to go it alone in their economic, financial, and regulatory policies. International cooperation is thus essential if we are to address the crisis successfully and provide the basis for a healthy, sustained recovery.").

89 Timothy Geithner, U.S. Sec. of the Treasury, Statement at International Monetary and Financial Committee (IMFC) Meeting (Apr. 25, 2009), https://www.treasury.gov/press-center/press-releases/Pages/tg104.aspx [https://perma.cc/7VKP-9C8N].

90 Ben S. Bernanke, The Courage to Act: A Memoir of a Crisis and ItS AFTERMATH 454 (2015).

91 Timothy Geithner, Stress Test: Reflections on Financial Crises 400 (2014). 
Members of Congress at the time. ${ }^{92}$ There was, however, a notable skeptic in the executive branch, who was heavily involved in U.S. activities at Basel and the FSB: Daniel Tarullo, then at the Federal Reserve, who quickly emerged as the institution's de facto leader on financial regulation. ${ }^{93}$

Tarullo's public statements at the time were circumspect, saying that "satisfyingly clean and comprehensive solutions" to international financial regulation were "not within sight."94 Some, however, were more pointed, as when he used apophasis to reference the U.K.'s actions on Lehman Brothers: "Some have called into question the traditional assumption that home country authorities will be willing and able to support all of the worldwide operations of a banking group headquartered in its jurisdiction." 95 Tarullo's academic writings were still more direct. In his 2008 book, Banking on Basel, Tarullo argued that "none of [the] potential advantages" of the Basel Committee's recent work were "both substantial and likely to be realized"; instead, Basel should focus on improving domestic authorities' oversight of their own banks. ${ }^{96}$ As a potent voice in the

\footnotetext{
92 In a later hearing, Congressman Michael Capuano of Massachusetts asked Bernanke a question about a Treasury initiative, saying that while "in some ways my questions should be addressed to Secretary Geithner. . . . [Y] ou have chosen to now get married, and once you are married, you do have to answer for your spouse." Bernanke responded, "We are not married. We are just good friends." An Examination of the Extraordinary Efforts by the Federal Reserve Bank to Provide Liquidity in the Current Financial Crisis: Hearing Before the House Committee on Financial Services, 111th Cong. 35 (2009), https://www.gpo.gov/fdsys/pkg/CHRG111hhrg48674/pdf/CHRG-111hhrg48674.pdf [https://perma.cc/3ZD2-MVK2].

93 Ryan Tracy \& Emily Glazer, The Most Powerful Man in Banking, WaLL ST. J. (May 31, 2016), http://www.wsj.com/articles/daniel-tarullo-the-one-man-judgeand-jury-for-banks-1464720855 [https:/ / perma.cc/XSK8-QKYD].

94 Daniel K. Tarullo, Governor U.S. Fed. Reserve Bd., Speech at the Institute of International Bankers Conference on Cross-Border Insolvency Issues, New York, New York: Supervising and Resolving Large Financial Institutions (Nov. 10, 2009), https://www.federalreserve.gov/newsevents/speech/tarullo20091110a.htm [https://perma.cc/5J4K-QRF2].

$95 \mathrm{Id}$.

96 TARULLO, supra note 12, at 10-11; see also Tarullo Biography, supra note 11, at 190 ("There is an undeniable attraction to a conceptually elegant mode of regulation that calibrates bank capital precisely to the risks associated with whatever credit exposures a bank may assume, whatever instruments it may trade, and whatever operations it may conduct. This attraction has perhaps come dangerously close to being a Siren song for at least some Basel II authors and defenders. One hopes that the subprime crisis has, if nothing else, injected sufficiently dissonant notes to catch the attention of Basel II believers").
} 
Federal Reserve and at Basel, Tarullo was well-positioned to turn his skepticism into U.S. policy.

\section{COOPERATION MEETS DEFECTION: THE DRAFTING OF DODD-FRANK}

The initial Obama Administration proposals for financial reform legislation reflected this mix of views within the executive branch: They placed a high premium on international cooperation, and they limited the ability of more skeptical, structurally insulated bureaucratic actors, such as the Federal Reserve, to diminish that cooperation.

The White House's first salvo in the reform debate was a 2009 white paper, dividing the administration's ideas for changing financial oversight into five separate objectives. ${ }^{97}$ The paper proposed that regulators give more attention to foreign financial firms, but only if those firms' "U.S. operations pose[d] a threat to financial stability." 98 The Federal Reserve would determine which firms posed such a threat, but only "in consultation with Treasury" and with "due regard to the principle of national treatment and equality of competitive opportunity." 99 In short, the white paper charged the Federal Reserve with hunting for risk among foreign banks in the United States - but only under the Treasury's supervision.

The Administration's first draft of financial reform legislation took a similar approach, giving the Federal Reserve authority to regulate the U.S. activities of foreign banks, but ensuring the Treasury would oversee the exercise of that authority. Section 204 of the draft allowed the Federal Reserve to designate any foreign bank with "substantial assets or operations in the United States" as a "Foreign Tier 1 financial holding company." 100 The Federal Reserve could not delegate this authority, and Treasury's only role in its application

97 U.S. DeP't of the Treasury, Financial Regulatory Reform - A NeW FOUNDATION: RebuILding FinANCIAL Supervision AND REgulation 1-2, https://www.treasury.gov/initiatives/Documents/FinalReport_web.pdf [https://perma.cc/4GUT-6MS9].

98 Id. at 84 (emphasis added).

99 Id. at $84-85$.

100 Administration Combined Draft Legislation for Financial Regulatory Reform, H.R. 4173, 111th Cong. § 204(a)(1)((B)(vi), LAW LIBRARIANs' SOC'Y WASH., D.C. (2009), http:/ / www.llsdc.org/assets/DoddFrankdocs/dodd-frank-act_admn-regreform-bill.pdf [https://perma.cc/6D7D-JG4A]. 
was through the Financial Stability Oversight Council, which the Treasury Secretary would chair and which could "recommend" firms for oversight.101 However, a separate section mitigated the Federal Reserve's ability to exercise this authority, requiring it and the Treasury to "consult with their foreign counterparties and through appropriate multilateral organizations to reach agreement to extend comprehensive and robust prudential supervision and regulation to all highly leveraged and substantially interconnected financial companies."102 Here, the Federal Reserve gained somewhat greater leeway, but its constraints took the form of legislative obligations, not bureaucratic ones from the Treasury.

However, Members of Congress - from both parties - met the international elements of the Administration's proposals with substantially more skepticism. Some, like Representative Ron Paul (RTX), railed against the Federal Reserve and its general lack of transparency, demanding to know "what we are doing when we are talking to foreign central banks, foreign governments, international organizations." 103

Others expressed concern that by relying on international cooperation, U.S. taxpayers would again have to subsidize the poor decisions of foreign banks. Representative Carolyn McCarthy (D-NY), citing AIG, said that "a significant amount, billions and billions, tens of billions of dollars, went to foreign banks.... I do not believe we should be bailing out foreign banks. I believe other governments should bail out their own banks."104 Representative Spencer Bachus (R-AL) claimed that "foreign banks . . . were paid dollar-for-dollar [on AIG claims] within hours of the bailout, and U.S. banks have yet

$101 \mathrm{Id}$.

$102 I d$. at $\S 204(\mathrm{k})$.

103 Regulatory Restructuring: Balancing the Independence of the Federal Reserve in Monetary Policy with Systemic Risk Regulation: Hearing Before the House Committee on Financial Services Subcommittee on Domestic Monetary Policy and Technology, 111th Cong. $\quad 4 \quad$ (2009), https://www.gpo.gov/fdsys/pkg/CHRG111hhrg53234/pdf/CHRG-111hhrg53234.pdf [https://perma.cc/9L7H-3X6H] (statement of Rep. Paul, Member, H. Comm. on Financial Services).

104 Perspectives on Regulation of Systemic Risk in the Financial Services Industry: Hearing Before the House Committee on Financial Services, 111th Cong. 32-33 (2009), https://www.gpo.gov/fdsys/pkg/CHRG-111hhrg48867/pdf/CHRG-

111hhrg48867.pdf [https://perma.cc/VKP9-Z9HR] (statement of Rep. McCarthy, Member, H. Comm. on Financial Services). 
to receive any payment . . ."105 Representative Brad Sherman (DCA) cited the "billions of taxpayer dollars transferred to foreign entities" as an embrace of "cowboy capitalism."106 Representative Jeb Hensarling (R-TX) said the Obama Administration had made AIG "a conduit for the transferring of taxpayer wealth to counterparties, some of which include foreign entities." 107 Members of the Senate made similar points, if less colorfully. ${ }^{108}$

When confronted with Congressional skepticism, most Administration officials defended the need for international cooperation. Comptroller of the Currency John Dugan, argued that "the global nature of today's financial institutions increasingly requires that supervisory policies and actions be coordinated and implemented on a global basis." 109 SEC Chair Mary Schapiro told a Senator that "[o]ur experience has confirmed the need for cross-border coordination and dialogue, as well as for sound regulatory regimes for

\footnotetext{
105 Addressing the Need for Comprehensive Regulatory Reform: Hearing Before the House Committee on Financial Services, 111th Cong. 3 (2009), https://www.gpo.gov/fdsys/pkg/CHRG-111hhrg48875/pdf/CHRG-

111hhrg48875.pdf [https://perma.cc/5EUC-WZJ6] (statement of Rep. Bachus, Member, H. Comm. on Financial Services).

106 Perspectives on Systemic Risk: Hearing Before the House Subcommittee on Capital Markets, Insurance, E Government Sponsored Enterprises, 111th Cong. 6 (2009), https://www.gpo.gov/fdsys/pkg/CHRG-111hhrg48863/pdf/CHRG-

111hhrg48863.pdf [https://perma.cc/K5Z5-HZDF] (statement of Rep. Sherman, Member, H. Comm. on Financial Services).

107 Systemic Risk and Insurance: Hearing Before the House Subcommittee on Capital Markets, Insurance, E Government Sponsored Enterprises, 111th Cong. 8 (2009), https://www.gpo.gov/fdsys/pkg/CHRG-111hhrg52400/pdf/CHRG111hhrg52400.pdf [https:// perma.cc/E7YK-A858] (statement of Rep. Hensarling, Member, H. Comm. on Financial Services).

108 See, e.g., Establishing a Framework for Systemic Risk Regulation: Hearing on S. 111-297 Before the Senate Committee on Banking, Housing, and Urban Affairs, 111th Cong. (2009) [hereinafter Establishing a Framework Hearing], https://www.gpo.gov/fdsys/pkg/CHRG-111shrg55278/pdf/CHRG-

111shrg55278.pdf [https://perma.cc/Y2K6-MCMW] (statement of Sen. Bunning, Member, S. Comm. on Banking, Hous., \& Urban Affairs) (asking each Obama Administration witness the same question: "AIG is probably the best known example of how problems can cross borders. How do we deal with the risk created in our country by actions somewhere else, as well as the impact of actions in the [United States] on foreign firms?"); see also Strengthening and Streamlining Prudential Bank Supervision: Hearing on S. 111-407 Before the Senate Committee on Banking, Housing and Urban Affairs, 111th Cong. (2009) [hereinafter Strengthening and Streamlining Hearing], https://www.gpo.gov/fdsys/pkg/CHRG-111shrg56376/pdf/CHRG111shrg56376.pdf [https://perma.cc/P6GM-KAJV].

109 Strengthening and Streamlining Hearing, supra note 108, at 88.
} 
principal subsidiaries of international holding companies."110 Geithner vigorously defended the need for a "level playing field that can be enforced more evenly, and so that risk can't just migrate to where it is going to face less strict supervision and oversight."111 Others, however, were more aligned with Tarullo and Congressional skeptics. FDIC Chair Sheila Bair invoked the Foreign Bank Supervision Act in her testimony, to suggest that the United States require foreign banks to operate only in separately capitalized subsidiaries. ${ }^{112}$

Congress's own reform legislation reflected the legislature's hesitancy about the regulation of foreign banks, giving more authority to domestic regulators and placing less emphasis on international fora. The initial bills drafted by Representative Barney Frank (DMA) and Senator Christopher Dodd (D-CT) merely left the detailed questions of foreign bank oversight almost entirely to the Federal Reserve.113 However, some proposed amendments were much harder on foreign banks - such as a pre-ratification draft of H.R. 4173, which gave the SEC and Federal Reserve the power to deny or revoke the charter of a bank whose home country "has not adopted, or made demonstrable progress toward adopting, an appropriate system of financial regulation to mitigate such systemic risk."114

\footnotetext{
110 Establishing a Framework Hearing, supra note 108, at 123.

111 The Administration's Proposals for Financial Regulatory Reform: Hearing Before the House Committee on Financial Services, 111th Cong. 33 (2009), https://www.gpo.gov/fdsys/pkg/CHRG-111hhrg54867/pdf/CHRG111hhrg54867.pdf [https:/ / perma.cc/43MR-XU7T].

112 See Establishing a Framework Hearing, supra note 108, at 110-15.

113 See Restoring Financial Stability Act of 2009 § 104 (Dodd Discussion Draft Nov. 10, 2009), http://www.llsdc.org/assets/DoddFrankdocs/bill-111th-s3217discussion-draft.pdf [https:// perma.cc/22NN-6MS4] (creating a new unified federal financial regulatory agency under Sen. Dodd's bill that would only apply heightened regulation to foreign banks with "due regard to the principle of national treatment and equality of competitive opportunity" and would try not to cause "sharp, discontinuous changes" with the new requirements); Financial Stability Improvement Act of 2009, H.R. 4173, 111th Cong. § 104, LAW LIBRARIANS' SOC'Y WASH., D.C. (2009), http://www.llsdc.org/assets/DoddFrankdocs/frank-treasury-discussion-draft_2009-10-27.pdf [https://perma.cc/V66D-8LX5] (showing Rep. Frank's joint draft with Treasury provided still less guidance to the Federal Reserve on foreign-banking-related rulemaking).

114 The Wall Street Reform and Consumer Protection Act of 2009, H.R. 4173, 111th Cong. \& 1951(l) (2009) https://www.gpo.gov/fdsys/pkg/BILLS111hr4173ih/pdf/BILLS-111hr4173ih.pdf [https:/ / perma.cc/76TD-AP3A].
} 
The final text of Dodd-Frank split the difference between these views, simultaneously embracing stricter regulation onshore and greater cooperation overseas. The stricter provisions were scattered throughout the Act; section 165 directed the Federal Reserve to issue more stringent requirements for non-bank financial companies - including bank holding companies, and thereby foreign banking organizations - which accounted for a bank's home-country regulations and gave "due regard to the principle of national treatment and equality of competitive opportunity."115 The Federal Reserve also gained the ability - but not the requirement-to restrict the activities of any foreign bank threatening U.S. financial stability. ${ }^{116}$ Section 156 required the U.S. Executive Director of the IMF to oppose any international loan "not likely to be able to [re]pay its obligations [in full]." 117 Section 167, for the first time, codified the source-of-strength doctrine into law. 118

However, these tougher provisions, giving greater authority over foreign bank operations to domestic regulators, stood in stark contrast to more internationalist ones. Section 275 directed the SEC and CFTC to "consult and coordinate with foreign regulatory authorities" and authorized them to "agree to such information-sharing arrangements as may be deemed to be necessary or appropriate in the public interest" around the regulation of swaps and derivatives. ${ }^{119}$ Section 175 went further, by effectively codifying United States involvement in Basel, requiring the Federal Reserve and Treasury Secretary to "consult with their foreign counterparts and through appropriate multilateral organizations to [encourage] comprehensive and robust prudential supervision and regulation to all highly leveraged and substantially interconnected financial companies." 120

$115 \mathrm{Id}$. at $\S 165$.

$116 I d$. at $\S 121$; see also Id. at $\S 173-74$.

117 Id. at $\S 156$.

118 Id. at § 167; see also Paul L. Lee, The Source-of-Strength Doctrine: Revered and Revisited - Part II, 129 BANKING L.J. 867 (2012) (analyzing the source-of-strength doctrine in relation to the Dodd-Frank and how it has changed in light of this new Act).

119 The Wall Street Reform and Consumer Protection Act of 2009, H.R. 4173, 111th Cong. $\S 275$ (2009).

$120 \mathrm{Id}$. at $\S 175$. 


\section{BUREAUCRATIC POLITICS AND LOW-PUBLIC-SALIENCY REFORM}

Despite the early backlash over "foreign bailouts," it is unlikely that the split outcome was the result of popular political pressure. Financial reform legislation took shape in the middle of the conservative "tea party wave," which reclaimed control of Congress in November 2010 and advocated total opposition to any measure that President Obama favored. ${ }^{121}$ Popular support for financial reform was divided along party lines, with Democrats favoring increased bank regulation by fifty-three points and Republicans opposing it by forty-eight. ${ }^{22}$ However, financial reform was neither the most salient nor the most polarizing issue that Congress was debating at the time. A contentious climate change bill,123 a $\$ 3.5$ trillion federal budget, 124 and comprehensive national healthcare reform were also on the legislative agenda.125 Though polling on the issue saliency of

121 Rebecca Ballhaus, A Short History of the Tea Party Movement, WALLST. J. (Feb. 27, 2014), http://blogs.wsj.com/washwire/2014/02/27/a-short-history-of-thetea-party-movement/ [https://perma.cc/WPD9-TMP3]; see also Christopher S. Parker, Wither the Tea Party? The Future of a Political Movement, 66 BROOKINGS INST. IsSUES IN GOVERNANCE STUDIES 1 (2014), https://www.brookings.edu/wp-content/uploads/2016/06/Parker_TeaParty.pdf [https://perma.cc/2GTG-X9RT] (providing the Tea Party's history).

122 Lydia Saad, Banking Reform Sells Better When 'Wall Street' is Mentioned, GALLUP (Apr. 20, 2010), http://www.gallup.com/poll/127448/banking-reformsells-better-wall-street-mentioned.aspx [https://perma.cc/Z6UB-99ZJ] (demonstrating that Democrats are more likely to support banking reform than Republicans.).

123 Daniel J. Weiss, Anatomy of a Senate Climate Bill Death, CTR. FOR AM. PROGRESS (Oct. 12, 2010), https://www.americanprogress.org/issues/green/news/2010/10/12/8569/anatomy-of-a-senate-climate-bill-death/

[https://perma.cc/SHS2-XRWH] (stating Republicans took a view of opposing Obama administration proposals that would increase his popularity); see also S. REP. No. 1733 (2010), https://www.congress.gov/bill/111th-congress/senatebill/1733/related-bills [https://perma.cc/V2L7-GVWD].

124 Carl Hulse, Budgets Approved, With No G.O.P. Votes, N.Y. Times (Apr. 2, 2009), http://www.nytimes.com/2009/04/03/us/politics/03budget.html [https://perma.cc/8S87-NN35] (discussing the importance of the budget for the Obama Administration).

125 See Norm Ornstein, The Real Story of Obamacare's Birth, THE ATLANTIC (July 6, 2015), http://www.theatlantic.com/politics/archive/2015/07/the-real-storyof-obamacares-birth/397742/ [https://perma.cc/XQC8-DPU4] (noting healthcare was at the top of President Obama's legislative agenda). 
financial reform is almost nonexistent, 126 it is plausible-even likely - that these other issues took priority for engaged constituents, especially as compared to minutiae of financial regulation like Basel participation and subsidiarization. ${ }^{127}$

If everyday voters were focused elsewhere, one might conclude that domestic politics had little to do with Dodd-Frank's divided stance on international cooperation. That conclusion would be consistent with the analysis Prof. Beth Simmons offers of a different policy agenda in her book, Mobilizing for Human Rights. 128 Human rights treaties are enforced, she argues, in part because they "influence the national policy agenda" and mobilize domestic actors around their cause. ${ }^{129}$ In the absence of other enforcement mechanisms, popular domestic politics gives these accords potency. By contrast, Basel, FATF, and their peer institutions seem like textbook cases of self-enforcing international agreements. From a rational institutionalist perspective, parties not only have an incentive to monitor and deter non-compliance (as the Lehman and AIG examples above show); they also have the ability to do so. ${ }^{130}$

126 See, e.g., Frank Newport, Economy Dominates as Nation's Most Important Problem, GALLUP (July 14, 2010), http:/ /www.gallup.com/poll/141275/economydominates-nation-important-problem.aspx [https://perma.cc/WCR8-UWEJ] (tracking polls from the time of Dodd-Frank's passage, including questions about the "most important problems" facing Americans, but failing to provide a specific option for financial regulation and reform).

127 See Stephen Mangan, JPMorgan CEO Says Bank Rules 'Anti-American,' REUTERS (Sept. 12, 2011), http://www.reuters.com/article/us-banks-basel-jpmorgan-idUSTRE78A3Z420110912 [https:// perma.cc/F2CN-5USJ]. In 2011, JPMorgan Chase \& Co.'s CEO Jamie Dimon received media attention after calling the Basel Committee "anti-American," long after Dodd-Frank was enacted and Basel III was underway. Id.

128 Beth A. SimmOns, MobiLizing FOR HumAn Rights: INTERNATIONAL LAW IN DOMESTIC POLITICs (2009).

${ }^{129} \mathrm{Id}$. at 114 (noting human rights treaties are not self-enforcing, but to ensure compliance, they should focus on how they influence domestic policies.).

130 See Chris Brummer, Why Soft Law Dominates International Finance-and Not Trade, 13 J. INT'L ECON. L. 623 (2011), https://academic.oup.com/jiel/article-abstract/13/3/623/875000?redirectedFrom=PDF [https://perma.cc/G8JF-HBQP]. Christopher Brummer has advocated this perspective, describing domestic supervisory sanctions as giving "soft law" a "hard edge" in international finance. However, he also describes this "hard edge" as a "name-and-shame" strategy, which dramatically understates the ability of domestic regulators in a financial center to punish non-compliant institutions. Within the Bank Secrecy Act/Anti-Money Laundering ("BSA/ALM") space, for example, a bank that fails to enact or abide by robust policies can incur civil money penalties, revocation of their operating license, 
Consider, for example, the practical options that Finland might have if it learned the Federal Reserve was letting U.S. banks bypass Basel Committee capital requirements. Barring any domestic legal restrictions, Finland could ease its own capital restrictions to boost the short-term profitability of its domestic banks, hoping they would take business from the Americans - or, more powerfully, it could bar its banks from doing business with U.S. financial institutions altogether. However, uncovering such perfidy might be harder or more expensive for a less financialized, less interconnected country like Finland. The Federal Reserve can place full-time examiners ${ }^{131}$ inside the dollar-clearing operations of large U.S. banks ${ }^{132}$ and punish them for transactions with overly "risk[y]" countries133; Finnish regulators may lack that same luxury. Organizations like the FSB and FATF help lower those costs of discovery. If the other FSB members drive those costs up too much by making unreasonable demands, then a country like Finland could exit the FSB, or simply let its own banks run amok - just as Bernanke and Geithner worried might happen in their memoirs. ${ }^{134}$ This process of establishing standards, monitoring compliance, and punishing defection is arcane, complex, and hard, and only regulators seem equipped to undertake it.

or even criminal charges. See, e.g., U.S. GOVERnMENT ACCOUNTABILITy OfFICE, FINES, Penalties, AND Forfeitures For Violations of FinANCial CRimes AND SANCTIONS REQUIREMENTS, GAO-16-297 (2016), http://www.gao.gov/assets/680/675987.pdf [https://perma.cc/JZX5-MMJ3]; Dan Fitzpatrick \& Scott Patterson, J.P. Morgan Criminal Case Could Trigger OCC Action, WALL ST. J. (Oct. 24, 2013), http://www.wsj.com/articles/SB10001424052702304682504579156022095052420 [https://perma.cc/22QW-5Y45].

131 Katy Burne, New York Fed Relocating Examiners out of Banks, WALL ST. J. (July 28, 2016), http:/ / www.wsj.com/articles/new-york-fed-to-relocate-examiners-outof-banks-1469743624 [https://perma.cc/6C8H-M95L] (noting federal regulators can decide where to put its examiners at any time).

132 Citibank, U.S. Dollar Clearing Services, (Dec. 23, 2016), https://www.citibank.com/tts/financial_institutions/payments/us_dollar.html

[https://perma.cc/9VWW-BZ5C] (providing example of a banking institution that provides dollar clearing services).

133 See, e.g., Fed. Fin. Inst. Examination Council, BSA/AML Risk AssessmentOverview (Dec. 7, 2016), https://www.ffiec.gov/bsa_aml_infobase/pages_manual/olm_005.htm [https:/ / perma.cc/6CPJ-U85X] (stating the BAS/AML risks of a bank determine the adequacy of the risk assessment process).

134 See BRUMMER, supra note 26, at 107-09; Bernanke, supra note 88; Geithner, supra note 91 (commenting that now people live in a financial environment where countries can no longer function independently of one another). 
On the surface, then, popular domestic politics might seem to have no real place in international financial regulatory accords. However, the Dodd-Frank Act suggests that this appearance is false. International financial regulation is not exempt from domestic politics, but the politics that shape it are distinct from those that shape less technical, more popularly salient issues. United States foreign policy around financial services takes many different forms - from FATF peer reviews and high-level G20 commitments, to domestic regulations that align with Basel Committee standards or enforce the source-of-strength doctrine, to federal legislation like DoddFrank with seemingly little extraterritorial effect. Each of these mechanisms constitutes a different aspect of America's interaction with the world on financial regulation - and the people and institutions responsible for each mechanism are different, as are their individual preferences and institutional incentives. Wherever these preferences and incentives are not perfectly aligned, politics occurs - even in the absence of public attention.

These politics - which are bureaucratic, rather than electoralmatter greatly to international policy outcomes. From 2008-2010, the U.S. President, his finance minister, and the head of his central bank consistently expressed their belief that multilateral solutions to financial regulatory problems were in their country's best interest. Their stated reasons ranged from competitive equity, to efficiency, to simple ethics. Whatever their reasons, however, when they exercised greater control over a policy process (e.g., among the G20, FATF, or Basel), the outcome of that process tended to more closely reflect their preferences. When they exercised less control over a process, like in Congress, the outcome tended to diverge from those preferences. To an outside observer, the result looks haphazard: policies that promise foreign businesses international harmonization and parity with domestic institutions, but which leave those businesses open to unique regulatory scrutiny. Pierce the national veil, however, and it becomes a clearer reflection of the official preferences and politics arrayed underneath.

This account of domestic politics is consistent with another branch of international relations scholarship: bureaucratic network theory. Anne-Marie Slaughter, extending her original thesis on the topic, proposed that bureaucrats operating in similar subject areas routinely cooperate across international borders, either forming policy independently or facilitating closer coordination through 
existing international institutions. ${ }^{135}$ David Zaring, building on Slaughter's work, argued that "[a]gencies like the [SEC] and the Federal Reserve Board now play roles as international lawmakers, and, in turn, are increasingly constrained by international agreement."136 Post-crisis financial policy, as Zaring ${ }^{137}$ and Brummer ${ }^{138}$ have separately written, helps corroborate Slaughter's idea that domestic agencies are critical actors in international law. However, DoddFrank demonstrates how those agencies - and the people who lead them - are also critical agents in domestic politics. If we are not surprised by the initiative, independence, and ability of those agents to act abroad, we should not be surprised when they exhibit the same traits at home.139

This dynamic should give succor to those concerned about the dearth of democratic accountability in bureaucratic networks. For example, Zaring has argued "the dramatic actions of the Fed during the financial crisis, none of which were subject to notice, comment, or judicial review, revealed just how far the central bank has strayed from the conventional procedures of an APA-mindful domestic

135 Anne-Marie Slaughter \& David T. Zaring, Networking Goes International: An Update, 2 AnN. Rev. L. \& SoC. SCI. 211, 225 (2006), https://papers.ssrn.com/sol3/papers.cfm?abstract_id=960484 [https://perma.cc/2UE669W9]. The differing ways that governmental networks operate makes it difficult to integrate them with international organizations; it is therefore easier to have independent networks coordinate.

136 David Zaring, Informal Procedure, Hard and Soft, in International Administration, 5 CHI. J. INT'L L. 547, 549 (2005), https:/ / papers.ssrn.com/ sol3/ papers.cfm?abstract_id=692764 [https:/ / perma.cc/T2VM-T6JJ].

137 David T. Zaring, Financial Reform's Internationalism, 65 EMORY L.J. 1255 (2016), https://papers.ssrn.com/sol3/papers.cfm?abstract_id=2809989 [https://perma.cc/7QYX-WTQQ] (developing the argument that financial reform has rebalanced the power of international engagement from the President and diplomats to independent agencies).

138 BRUMMER, supra note 26, at 19-20.

139 See Jonathan R. Macey, Regulatory Globalization as a Response to Regulatory Competition, 52 EMORY L.J. 1353, 1356 (2003), http://digitalcommons.law.yale.edu/cgi/viewcontent.cgi?article=2420\&context=fss_papers [https://perma.cc/8ETR-PRWT]. This idea suggests a modification to Macey's 2003 thesis on regulatory globalization. Macey argues that "regulatory globalization is likely to occur when there is a significant gulf between the policy preferences of an administrative agency and the policy preferences of one or more of its constituencies," including other agencies, other branches of government, or regulated entities. The Dodd-Frank case suggests that divergent preferences may push officials (elected or bureaucratic) towards greater engagement domestically, if others in government prefer international engagement. 
agency." 140 However, the outcomes these agencies reach are limited by the process that creates them, in which different actors, with different preferences, hold different amounts of authority at different times. Thus, there are many ways a concerned party could influence the exercise and distribution of that authority - not just at the federal level, (before Congress, agencies, and departments) or the supranational level (in, for example, comment letters to the Basel Committee), but at the state and local level, on issues like the scope and requirements of a state banking charter. The more institutionally diverse the process, the greater the chance domestic actors have to intervene, and the more electoral politics can influence or supersede bureaucratic politics, well before the water's edge.

140 David T. Zaring, Sovereignty Mismatch and the New Administrative Law, 91 WASH. U.L. REV. 59, 102 (2013), https://openscholarship.wustl.edu/cgi/viewcontent.cgi?article=6038\&context=law_lawreview [https: / perma.cc/ZHR5-TKN5]. 